DOI https://doi.org/10.18551/rjoas.2020-12.17

\title{
LEVEL OF MANGROVE DENSITY WITH USING NORMALIZED DIFFERENCE VEGETATION INDEX METHOD IN SORONG CITY AND ITS SURROUNDING AREA, WEST PAPUA PROVINCE OF INDONESIA
}

\author{
Ulat A.M., Ismail I. *, Razak D.A., Sururi M. \\ Marine and Fisheries Polytechnic of Sorong, Ministry of Marine Affair and Fisheries, \\ Indonesia \\ *E-mail: ismailabdullahumum@gmail.com
}

\begin{abstract}
The mangrove forest is a coastal ecosystem having high economic value for supporting fisheries activities. Monitoring to detect a change in mangrove condition has to be done continuously. One of way is the application of remote sensing technology with Citra Landsat $8 \mathrm{OLI}$ which had been used in many types of research to monitor the condition of mangrove forest. This study was carried out to reveal changes in the density of mangrove vegetation in Sorong City. The method used was the Normalized Different Vegetation Index (NDVI) values with the measuring of mangrove vegetation started from 2012 to 2018 period. The result of this study was the high dense level was in increasing 568.08 ha, the medium dense level was in increasing $12.03 \mathrm{ha}$, and the low, dense level was in decreasing 153.09 ha. This showed that the high dense level was better than both the medium and the low level. According to KEPMLH No. 201 Year 2004 that condition of mangrove density level in Sorong City and its surrounding area, West Papua Province was included a good category.
\end{abstract}

\section{KEY WORDS}

Vegetation, NDVI, density level, Sorong.

Mangrove forests act as sediment traps, nutrient cycling, abrasion barriers, and affect fishery production (Lee 2014). reducing the greenhouse effect (Murdiyarso et al. 2015), providing food, firewood, timber and tannins (FAO, 1994; Hamilton and Snedaker, 1984), while mangrove waters themselves serve as a habitat for fish resources (Irwandi and Suryono 2012), as a shelter for larvae and juveniles of various fish, shrimp and crab species and spawning grounds (Odum and Heald 1972; Baran and Hambrey 1998; Field et al., 1998). Laegdsgaard and Johnson 2001; Man $\urcorner$ son et al. 2005; Nagelkerken et al. 2008), food supply for fish (Saenger et al. 2013), supporters of fish population growth (Castellanos et al. 2013), providers of sustainable primary aquatic productivity (Alongi 2002) and nearly $90 \%$ of marine biota species have been found in mangrove ecosystems ( Snedaker 1978). This critical role ensures the production of mangrove fisheries (Samosir et al. 2010), especially mangrove crabs (Ismail et al. 2019).

Currently, mangrove forests, especially in coastal cities, are under pressure. Globally, the mangrove area has decreased by $1-2 \%$ per year (Alongi, 2015). If this condition continues, it will have an impact on the lives of fishers and coastal communities who depend on the mangrove ecosystem. Monitoring the situation of mangrove forests is an important thing to do to anticipate the impact on the sustainability of fish resources and their habitats.

The area of Sorong City as a coastal city has a mangrove ecosystem. Commonly people come to mangrove ecosystem to find fish, shrimp and crab. On the other hand, the population growth and development of Sorong City which is relatively high at this time has led to an increase in land needs, resulting in the conversion of mangrove land for settlement and illegal logging of mangroves. This condition resulted in a decrease in mangrove vegetation density. Therefore we need an analysis of the density level of mangrove forest vegetation in the city of Sorong and its surroundings.

Aim of this study is to analyze the level of mangrove vegetation density in Sorong City and its surroundings as an effort to support sustainable mangrove fisherie. 


\section{METHODS OF RESEARCH}

The research location is mangrove forest vegetation in the city of Sorong and its surroundings, West Papua Province with coordinates $131^{\circ} 12^{\prime} 0^{\prime \prime}-131^{\circ} 20^{\prime} 0^{\prime \prime}$ east longitude and $0^{0} 52^{\prime} 0^{\prime \prime}-0^{0} 59^{\prime} 0^{\prime \prime}$ south latitude. The satellite data used is Landsat 8 Path 107 / Row 061 satellite imagery. Types of image data are as shown in Table 1. The tools used in this study include laptops that have installed the ArcGIS 10.4.1 application, ER Mapper 7.1, Microsoft Excel, and Microsoft Word. The materials used in this study are shown in Table 1.

Table 1 - Types and sources of research data

\begin{tabular}{ll}
\hline Data type & Source \\
\hline Citra Landsat 8 OLI & www.earthexplorer.usgs.gov \\
Sorong city map & www.tanahair.indonesia.go.id \\
\hline
\end{tabular}

The research stages included data collection, image data pre-processing, image data processing which consisted of finding the area of mangrove vegetation and the distribution of mangrove density, and overlay. The stage flow chart in this study is shown in Figure 1.

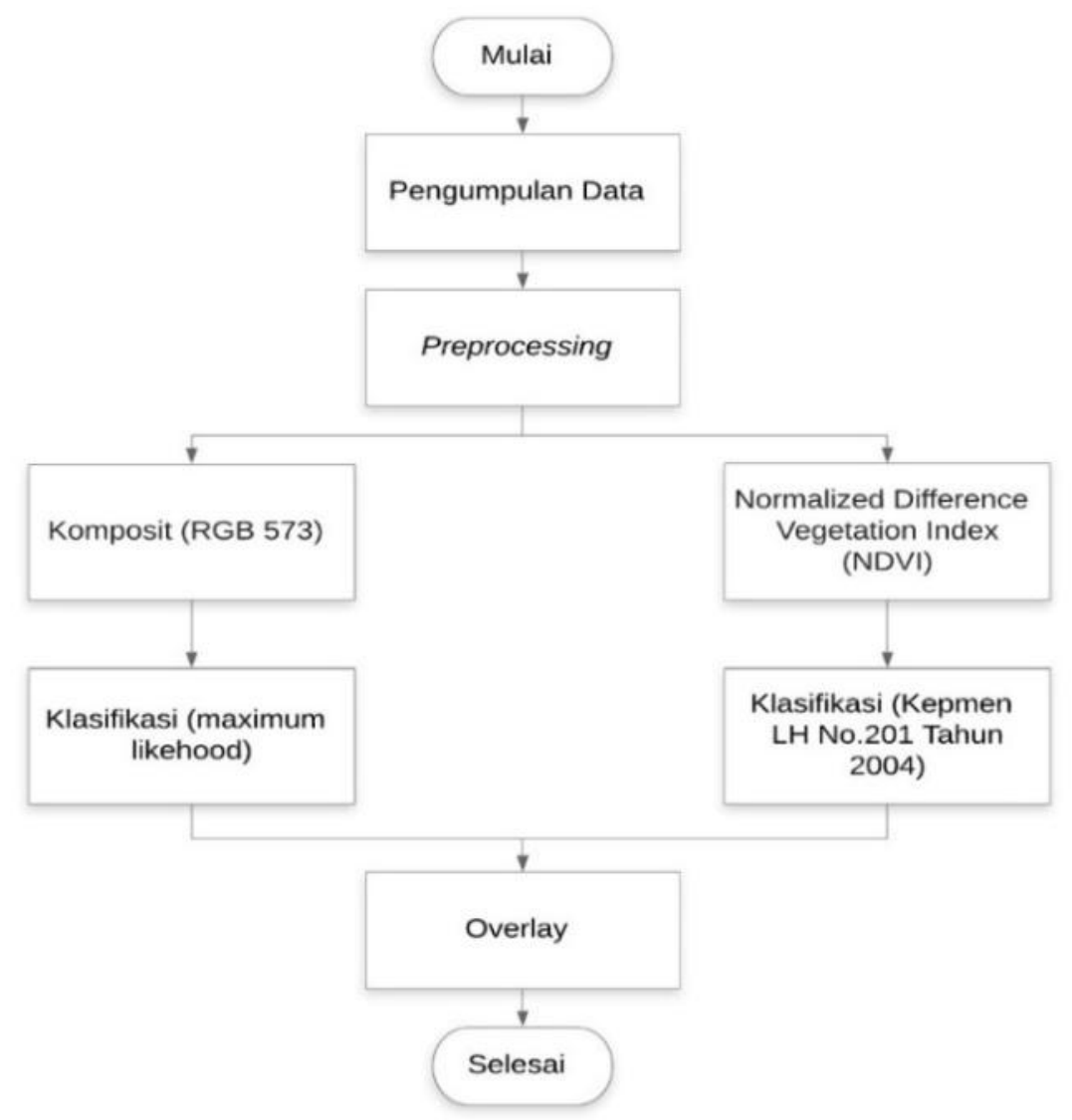

Figure 1 - Stages of research on mangrove density using the NDVI method

Mangrove vegetation density data were obtained from Landsat 8 imagery acquired in 2012, 2014, 2016 and 2018 using the Normalized Difference Vegetation Index (NDVI) method. The NDVI formula:

$$
N D V I=\frac{N I R-R e d}{N I R+R e d}
$$

Where: NIR = Near-Infrared; Red = Red canal. 
The level of mangrove vegetation density refers to KEPMLH No. 201 of 2004 as modified by Waas and Nababan (2010). NDVI values are classified into three classes, which are sparse, moderate and dense class, as illustrated in Table 2.

Table 2 - Mangrove density levels based on NDVI values

\begin{tabular}{lll}
\hline Vegetation Density Level & Tree Density (Individual/Ha) & NDVI \\
\hline Sparse & $<1000$ & $0.10-0.20$ \\
Moderate & $1000-1500$ & $0.20-0.30$ \\
Dense & $>1500$ & $>0.30$ \\
\hline
\end{tabular}

The results of the data processing are presented in a thematic map i of the distribution of mangrove vegetation density in Sorong City and its surroundings, West Papua Province, according to the class that has been determined.

\section{RESULTS AND DISCUSSION}

Based on the results of processing OLI Landsat 8 satellite imagery in 2012, 2014, 2016 and 2018, the distribution of mangrove vegetation density is obtained as shown in Figure 1.

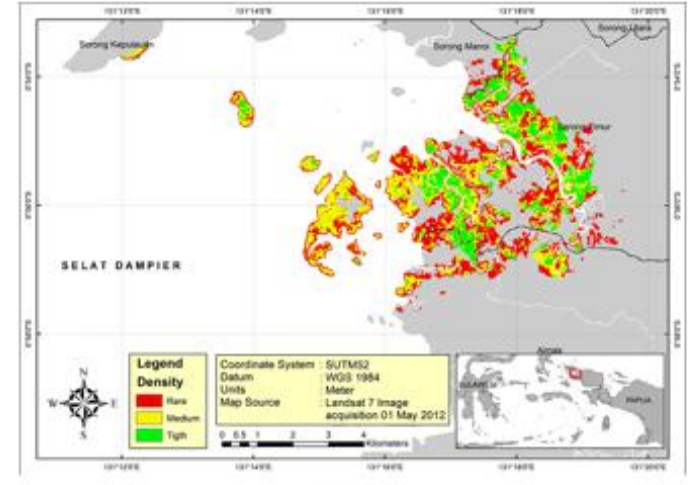

2012

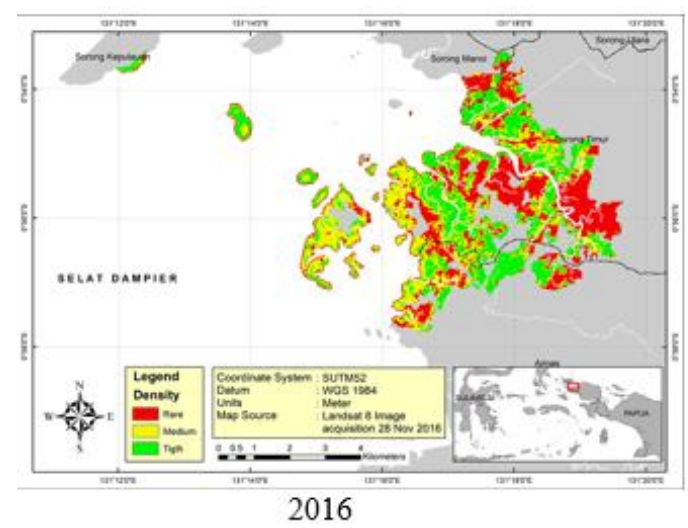

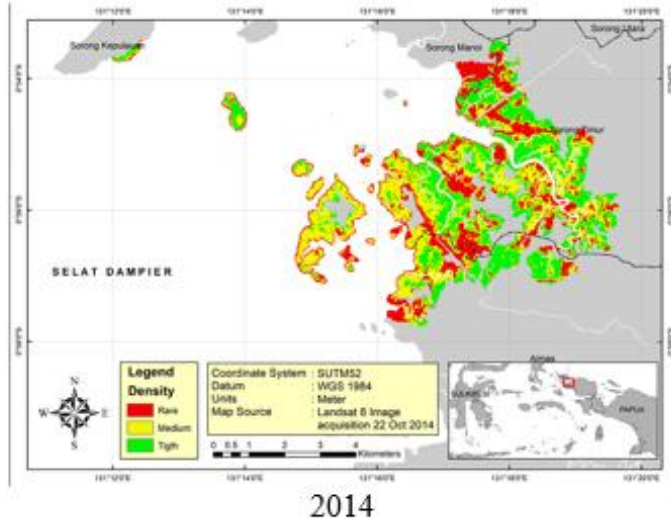

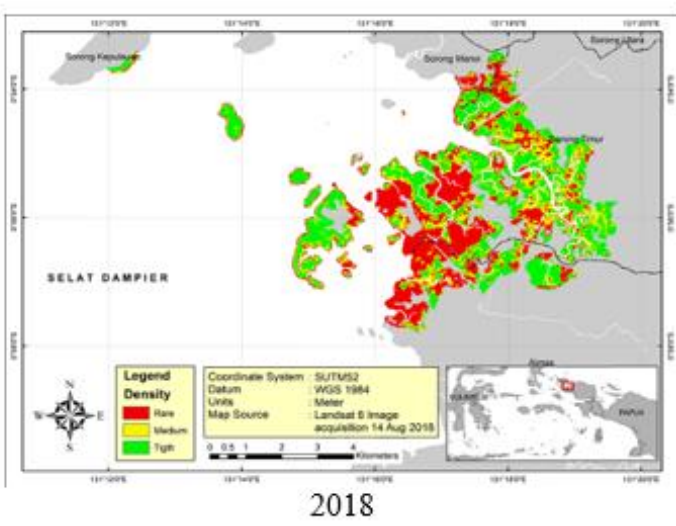

Figure 1 - Changes in the density level of mangrove vegetation in the City of Sorong and surroundings from 2012, 2014, 2016 and 2018.

Figure 1 shows that based on the spatial distribution, the change in vegetation density varies, while based on temporal, the mangrove density of the same location can change from "Sparse Level" to "Moderate Level" and from " Moderate Level" to "Dense Level" as well. Otherwise. For more details, changes in the density level of mangrove vegetation in Sorong City and its surroundings can be explained in the form of a histogram as in Figure 2.

Based on Figure 2, it shows that during the 2012-2018 period the density of mangrove vegetation "dense level" increased by 568.08 ha and "sparse level" increased by 12.03 ha, while in the "moderate-level" mangrove canopy density decreased by 153, 09 ha. Besides, 
the percentage of mangrove vegetation density fluctuates. The percentage of sparse and medium mangrove density tends to decrease, while the percentage of dense mangrove density tends to increase, as shown in Figure 3.

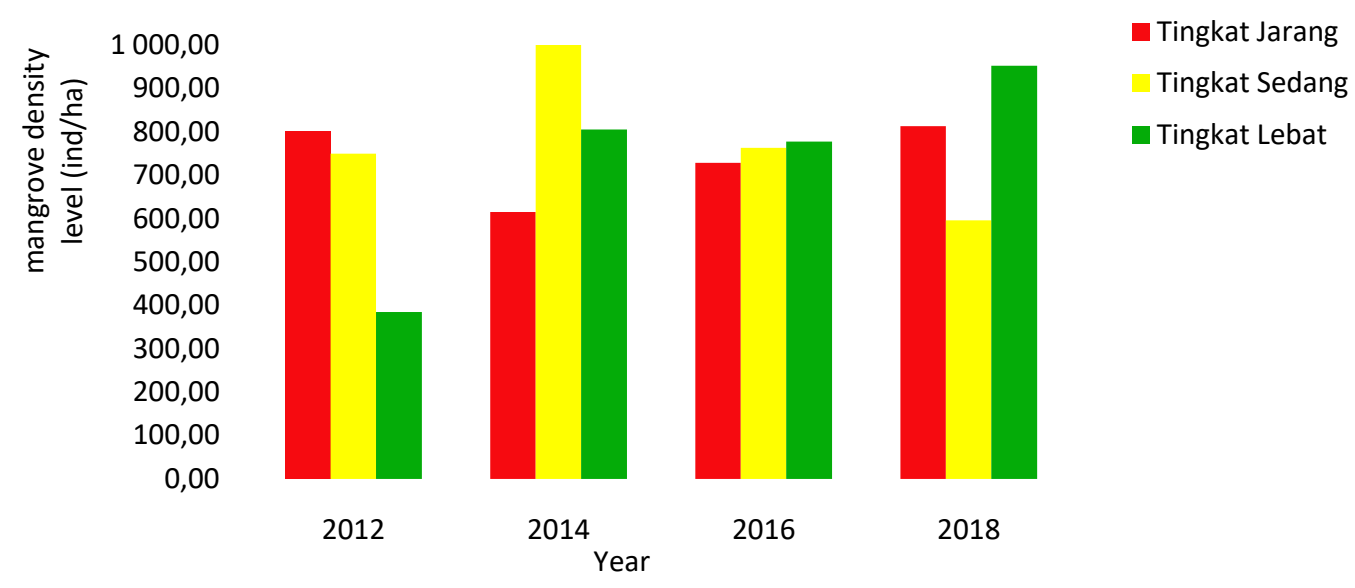

Figure 2 - The density of mangrove vegetation for 2012-2018 period
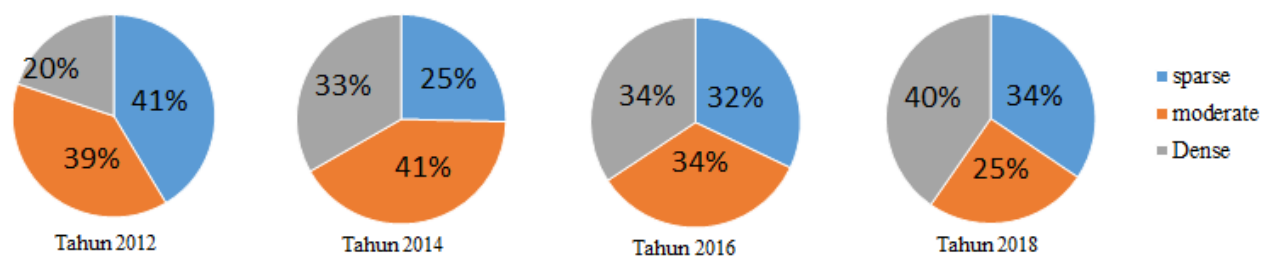

Figue 3 - Percentage of mangrove vegetation density in Sorong City and its surroundings

During the 2012-2018 period, in general, the density of mangrove vegetation in Sorong City, both in the "rare level" category and the "medium-level" category, decreased sequentially, namely by $6.97 \%$ and $13.48 \%$, while the "dense level" category experienced an increase. $20.45 \%$, but in this dense level of mangrove areas, there are many mangrove associations from Derris spp. This shows that mangrove tree cutting is still ongoing.

This feeling causes the density of the mangrove forest canopy to become more open so that the penetration of sunlight penetrates the mangrove forest floor; this is beneficial for Derris spp. Because this type of mangrove is a plant that likes to grow in open mangrove forest areas, receives lots of sunlight, forms dense clumps. Because of this suitable habitat, Derris spp can easily invade the mangrove forest floor area.

The presence of Derris spp is a sign of the degradation of mangrove forests. Furthermore, it is suspected that there is a change in mangrove density from "sparse level" to "dense level".

Ardli et al. (2010) stated that the Derris spp and Acanthus spp species dominate a particular area because these species have a double breeding system, sexually and asexually. Both of these species are very easy to grow in open environments due to logging of mangrove trees or forms of land conversion.

Suppose the conditions change in mangrove density lasts long enough. In that case, it can affect the stability of water temperature and decrease dissolved oxygen and can change the composition of the mud substrate organisms on the mangrove forest ground. The condition is supporting Soenarjo (1999) study that the openness of mangrove forests will affect the aquatic environment such as temperature, salinity, $\mathrm{pH}$, current velocity, brightness, dissolved oxygen (DO), substrate composition and substrate microorganisms. Which subsequently may have an impact on the abundance and diversity of fish species. Rinaldi et al., 2017; Vincentius et al., 2019. This condition also occurs in mangrove forests in Segara Anakan, Cilacap Regency, where the density of the "dense level" mangrove canopy is 
dominated by Derris spp and Achantus spp (Ismail et al. 2018). During the research, the local community still found illegal logging of mangroves for house poles, flagpoles and firewood.

The increase in mangrove density by the Derris spp species above indicates that the condition of the mangrove ecosystem in Sorong City and its surroundings is experiencing a change from significant mangrove forests which form pure stands to associated mangrove forests which tend to be invasive. Suppose this goes on for a long time. It will have an impact on the aquatic habitat of fish resources, especially mangrove crabs (Ismail et al. 2019). which require thick mud that comes from the mixed results of the Rhizophora root structure, also shrimp that live in shallow waters in front of the mangrove (Barbier, EB, Strand. 1998), and will ultimately reduce fishery production in the future (Mahmudi 2010; Mauricio et al. 2013).

\section{CONCLUSION}

Based on the NDVI assessment, mangrove density at dense and medium levels has increased, while low-level mangrove density has decreased. The increase in mangrove density at the dense level is more significant than the moderate level, and this shows that the mangrove density of Sorong City and its surroundings is suitable habitat and nursery groundfish resources for sustainable mangrove fisheries.

\section{REFERENCES}

1. Alongi DM. 2002. Present state and future of the world's mangrove forests. Environmental Conservation 29, 331-349.

2. Alongi D. 2015. The Impact of climate change on mangrove forest. Curr Clim Change $\operatorname{Rep~(1):30-39.~}$

3. Alphonse A, Ibrahim I T, Adam G.2013. Fish Assemblages in the Degraded Mangrove Ecosystems of the Coastal Zone, Benin, West Africa: Implications for Ecosystem Restoration and Resources Conservation Journal of Environmental Protection.(4), 14611475.

4. Ardli ER, Widyastuti, Adan Yani E. 2012. Penggunaan Acanthus illifolius and Derris trifoliata sebagai agen biomonitoring kerusakan mangrove Segara Anakan Cilacap. Laporan Penelitian. Purwokerto. Fakultas Biologi Universitas Jenderal Soedirman.

5. Barbier, E.B., Strand, I. Valuing Mangrove-Fishery Linkages - A Case Study of Campeche, Mexico. 1998. Environmental and Resource Economics 12, 151-166.

6. Barbier, E.B., Cox, M., 2003. Does economic development lead to mangrove loss? A cross-country analysis. Contemporary Economic Policy 21 (4), 418-432.

7. Beveridge, M.C.M. 1984. Cage and pen fish farming: Carrying capacity models and environment impact. FAO Fisheries Technical Paper 225. FAO-UN Rome.

8. [FAO] Food and Agriculture Organization of the United Nations. 1994. Mangrove forest management guidelines. FAO Forestry Paper 117. Rome (IT). Italy.

9. FAO, 2007. The world's mangroves 1980-2005. A thematic study prepared in the framework of the Global Forest Resources Assessment 2005. FAO Forestry Paper 153. Food and Agriculture Organization of the United Nations, Rome (IT), Italy.

10. Field CB, Osborn, JG., Hoffman, L.L., Polsenberg, J.F., Ackerly, D.D., Berry, J.A., Bjorkman, O., Held, A., Matson, P.A., Mooney, H.A., 1998. Mangrove biodiversity and ecosystem function. Global Ecology and Biogeography Letters 7 (1), 3-14.

11. Field, C.D., 2000. Mangroves. Seas at the Millennium - An Environmental Evaluation Vol. 3. pp. 17-32.

12. Gilbert, A.J., Janssen, R., 1998. Use of environmental functions to communicate the values of a mangrove ecosystem under different management regimes. Ecological Economics 25 (3), 323-346.

13. Hutchison J, Spalding M and Ermgassen P. 2014 The Role of mangroves in fisheries enhancement The Nature Conservancy and Wetlands (International University of Cambridge United Kingdom). 
14. Hutchison J, Philipp DP, Claussen JE, Aburto-Oropeza O, Carrasquilla-Henao $M$, CastellanosGalindo GA, Costa MT, Daneshgar PD, Hartmann HJ, Juanes F, et al. 2015. Building an expert-judgment-based model of mangrove fisheries. Am Fish Soc Symp. 83(4):17-42.

15. Irwani and Suryono CA. 2012. Pertumbuhan Kepiting Bakau Scylla serrata di Mangove Buletin Oseanografi Marina. (1) $15-19$.

16. Lugo AE, Snedaker SC.1974. The ecology of mangroves. Annual Review of Ecology and Systematics. (5) 39-64.

17. Manson F J, Loneragan N R, Harch B D, Skilleter G A and Williams L 2005 A BroadScale Analysis of Links Between Coastal Fisheries Production and Mangrove Extent $A$ Case-Study for Northeastern Australia Fish. Res. 74 69-85.

18. Mauricio Carrasquilla-Henao Héctor A.González OcampoAntonioLuna González Gerardo Rodríguez Quiroz. 2013. Mangrove forest and artisanal fishery in the southern part of the Gulf of California, Mexico Ocean and Coastal Management 83, 75-80.

19. Murdiyarso D, Purbopuspito J, Kauffman JB, Warren M, Sasmito S, Donato, D. Kurnianto S. 2015. The potential of Indonesian mangrove forests for global climate change mitigation. Nature Climate Change. 5.1089-1092.

20. Rönnbäck, P. 1999. The ecological basis for economic value of seafood production supported by mangrove ecosystems. Ecological Economics, 29 : 235-252.

21. Sandoval Londoño LA, Leal-Flórez J, Blanco-Libreros JF.2020. Linking mangroves and fish catch: a correlational study in the southern Caribbean Sea. Bulletin of Marine Science. 96. 1-16.

22. Soenardjo N. 1999. Produksi and laju dekomposisi serasah mangrove and hubungannya dengan struktur komunitas mangrove di Kaliuntu Kabupaten Rembang Jawa Tengah. [tesis]. Bogor: Sekolah Pascasarjana IPB.

23. Vitousek, P.M. 1982. Nutrient cycling and nutrient use efficiency. American Naturalist, 119: 53-72.

24. Vincentius A, M N Nessa, J Jompa and A Saru. 2019. Complex Relationship between Mangrove Ecosystem Variables and Fish Assemblages at Maumere Bay, Indonesia. IOP Conference Series: Earth and Environmental Science, Volume 253, MarSave International Symposium 2018: "Strengthening Marine Resilience for Sustainable Development Goals" 7-8 August 2018, Makassar, South Sulawesi, Indonesia.

25. Vincentius A, Nessa M N, Jompa J, Saru A, Nurdin N and Rani C 2018 Influential factors analysis towards mangrove cover and production of demersal fish in Maumere Bay Indonesia AACL Bioflux 11 810-822. 